\title{
PERAN KAPITALISME GLOBAL DALAM PENYEBARAN IDEOLOGI RADIKAL DI MEDIA SOSIAL
}

\author{
Ignasius Liliek Senaharjanta \\ Fakultas Ilmu Sosial dan Humaniora, Universitas Bunda Mulia \\ isenaharjanta@bundamulia.ac.id
}

\begin{abstract}
The rapid development of information technology throughout the last few decades brings about a new color in the spread of information pattern. The availability of internet supported by the latest information technology, enables the media to spread information without limitation of space and time. Some issues addressed in this paper: how is the role of global capitalism in the spread of radical idelogy through social media? Furthermore, how is the inter-countries relation with regard to the spread of radical ideology? And what form of economy is created by the capitalisation of radical idelogy? Last but not least, what kind of actions being done by global network in order to advance security and to prevent the spread of radical ideology? The spread of radical ideology through social media has become study in contemporary global issues. This is because the relation of economy and political globalization is hardly separated. The economic gain of the global spread of radical ideology through social media will be qualitatively described in this paper. The act of spreading radical ideology using information technology brings benefit to the capitalist. Moreover, revolution of communication technology which also promotes globalization has raised awareness among nations: there is a problem that cannot be solved independently. Lastly, globalization also makes problem solving possible with the support of other countries.
\end{abstract}

Keywords: Globalization, Radical Ideology, Social Media, Capitalism Global

\section{PENDAHULUAN}

Perkembangan teknologi informasi yang sangat pesat pada beberapa dekade belakangan ini telah memberikan warna baru dalam pola penyebaran informasi. Kehadiran internet yang didukung dengan teknologi informasi terkini memungkinkan siapa pun dapat melakukan penyebaran informasi tanpa batasan ruang dan waktu. Website, blog, media online, media sosial, cloud computing, merupakan sebagian media baru yang lahir akibat dari perkembangan internet. (Nasrullah, 2017:39). Dampak dari kehadiran internet tidak saja dirasakan oleh media tetapi juga berimbas pada perubahan pola perilaku komunikasi masyarakat. Perubahan tersebut tampak ketika masyarakat berinteraksi atau melakukan komunikasi melalui jejaring media sosial (Nasrullah, 2017:9). Masyarakat saat ini lebih memilih untuk melakukan komunikasi dengan menggunakan media sosial atau aplikasi percakapan, ketimbang bertatap muka secara langsung. Bahkan, perilaku ini tidak jarang dilakukan ketika individu saling berdekatan satu sama lain atau jarak yang tidak terlalu jauh.

Perubahan perilaku komunikasi tersebut telah menjadi fenomena yang penting dalam kajian studi media saat ini. Hal tersebut menarik untuk dicermati karena masyarakat saat ini masuk pada masa peralihan dari bentuk-bentuk komunikasi "tradisional" ke bentuk komunikasi digital. Keberadaan berbagai platform media sosial seperti Facebook, Twitter, Path, Instagram maupun jejaring sosial lainnya saat ini menjadi pilihan utama dalam berkomunikasi. Hal ini disebabkan karena media sosial memiliki karakteristik yang dapat menjangkau komunikasi secara lebih luas dan massif. Selain itu, media sosial juga menawarkan berbagai fitur lengkap untuk mendukung kemudahan komunikasi para penggunanya. Fitur yang terdapat dalam media sosial terdiri dari teks, foto dan audio visual. Dalam prakteknya berbagai fitur tersebut menjadi atraksi tersendiri dan dimanfaatkan oleh masyarakat untuk membuat komunikasi lebih menyenangkan. Masyarakat 
berkomunikasi melalui media sosial dengan menampilkan gabungan antara teks, foto, dan audio visual (Nasrullah, 2017:40)

Fitur atau "fasilitas" menarik yang ditawarkan oleh media sosial mendorong masyarakat untuk selalu melakukan pembaharuan (update) terhadap status di akun media sosialnya. Bentuk pembaharuan status ini tidak saja dipergunakan untuk berkomunikasi, tetapi juga dimanfaatkan sebagai sarana untuk membentuk citra atau self branding bagi penggunanya. Pencitraan tersebut dilakukan dengan membagikan beragam bentuk isi pesan. Mulai dari status liburan, pengalaman pribadi, prestasi, info kuliner, info produk, sampai pada hal-hal yang bersifat pribadi. Pesan yang dibagikan tersebut kemudian akan direspon atau mendapatkan feedback berupa like, love atau komentar dari publik yang juga mengakses media sosial yang sama atau menjadi follower dari akun yang diikutinya (Nasrulah, 2017: 125-136).

"Atraksi" yang diberikan oleh media sosial tidak saja menarik minat masyarakat secara individu, tetapi daya tariknya juga dimanfaatkan oleh organisasi untuk mencapai tujuan tertentu, misalnya promosi produk, sarana komunikasi dengan pelanggan, kampanye, jual-beli secara daring, mempublikasikan berita, menggalang dana dan lain-lain. Bahkan, tidak jarang media sosial juga digunakan sebagai sarana propaganda untuk tujuan politik tertentu. Hal ini dapat dilihat dari berbagai peristiwa politik yang berawal dan menggunakan media sosial sebagai sarana untuk menggalang dukungan. Misalnya Revolusi di Mesir pada tahun 2011 yang dikenal dengan "Arab Springs". Aktivis pro perubahan pada waktu itu memanfaatkan Facebook dan Twitter sebagai sarana menggalang dukungan untuk menggulingkan Presiden Hosni Mubarak. Selain itu, aksi serupa juga dilakukan oleh para mahasiswa pada tahun 2014 di Hongkong. Revolusi yang dikenal dengan "Revolusi Payung" tersebut merupakan bentuk protes atas kebijakan Pemerintah yang merevisi peraturan pemilihan kepala pemerintahan secara langsung. Gelombang protes dalam jumlah yang besar tersebut merupakan gerakan yang dimulai dari media sosial. Indonesia sendiri pernah mengalami peristiwa yang sama dengan peristiwa politik yang terjadi di luar negeri (www.tirto.id). Gerakan aksi 212 yang mengakibatkan Gubernur DKI Jakarta menjadi terdakwa dengan tuduhan penistaan agama. Gerakan tersebut dipicu dari potongan video yang diunggah oleh Buni Yani di Facebook dan terus berkembang menjadi aksi massa yang digalang melalui media sosial (www.cnnindonesia.com).

Dampak yang luas dan signifikan dari penggunaan media sosial tidak saja dapat digunakan untuk menggalang dukungan dan mencapai tujuan tertentu. Namun, media sosial juga mampu merasuk lebih dalam dengan mempengaruhi pola pikir dan perspektif seseorang secara massif. Pola komunikasi dan interaksi dalam media sosial menyebabkan seseorang hanya berpikir sekilas dalam menilai sesuatu. Artinya, terpaan dari media sosial dapat mempengaruhi pola pikir dan perilaku seseorang (Kompas, 19 Januari 2018). Kelompok Negara Islam dan Suriah (NIIS) yang sejak 2013 telah menggunakan berbagai platform media sosial seperti Facebook, Twitter, Youtube, dan Telegram tampaknya memahami sifat dari media sosial yang terbuka untuk umum, mudah diakses oleh siapa pun dan penyebarannya hampir tidak bisa dihambat. (Kompas, 27 Desember 2017)

Oleh sebab itu, kelompok NIIS kerap melakukan kampanye, provokasi, propaganda dan menyebarkan ideologinya secara radikal melalui internet dan media sosial. NIIS memanfaatkan media sosial tidak saja untuk menyebarkan paham radikalnya tetapi juga digunakan sebagai saluran komunikasi dan instruksi kepada para pendukungnya yang tersebar di berbagai negara. Instruksi yang disampaikan NIIS melalui media sosial diantaranya adalah instruksi kepada pendukungnya untuk melakukan teror di negaranya masing-masing dengan berbagai cara seperti serangan bom, serangan senjata tajam secara acak, bom bunuh diri dan serangan senjata api. (Kompas, 27 Desember 2017). Bahkan, NIIS juga menginstruksikan untuk mulai 
melibatkan anak-anak dan perempuan dalam melakukan serangan teror.

Di Indonesia sendiri dampak dari penyebaran ideologi radikal melalui media sosial yang dilakukan oleh NIIS cukup berpengaruh. Hal ini dapat dilihat mulai dari jumlah organisasi di Indonesia yang melakukan deklarasi dukungan terhadap NIIS, sampai dengan dukungan secara individu yang berangkat menuju Suriah untuk bergabung langsung dengan NIIS. Badan Nasional Penangulangan Terorisme (BNPT) mencatat sedikitnya terdapat 594 warga negara Indonesia yang berangkat ke Suriah. Sedangkan, pada 2016-2017 BNPT mencatat ada 50 buruh migran perempuan asal Indonesia yang terlibat dengan jaringan NIIS, dua diantaranya ditangkap karena diduga ingin melakukan serangan aksi bom bunuh diri (Kompas.com).

NIIS terus menyebarkan pengaruhnya dengan melakukan penyebaran ideologi radikal melalui media sosial. Bahkan, di Indonesia penyebaran ideologi radikal tersebut dilakukan dari dalam penjara oleh salah satu pimpinan Jamaah Ansharut Daulah (JAD), Aman Abdurahman. Aman memberikan instruksi dalam bentuk teks yang diposting ke media sosial kepada Jemaah JAD untuk melakukan serangkaian aksi teror menyerang pihak kepolisian.(Kompas, 20 Juni 2018) Maraknya penyebaran ideologi radikal melalui media sosial menjadi indikasi bahwa perjuangan yang dilakukan oleh para radikalis saat ini tidak saja dilakukan dengan mengangkat senjata, tetapi sudah mengalami pergeseran dengan mengikuti perkembangan dan memanfaatkan teknologi informasi.

Media sosial yang memiliki sifat terbuka dan menyebar ini sudah seharusnya dipergunakan untuk sesuatu yang positif, seperti berbagi informasi, sarana mengembangkan ketrampilan sosial dan ajang untuk menjalin pertemanan secara luas. Selain itu, media sosial juga dapat dimanfaatkan sebagai sarana untuk meningkatkan roda perekonomian dari para penggunanya. Jual-beli secara daring merupakan contoh positif dari memanfaatkan media sosial dari segi ekonomi. Mengikuti perkembangan teknologi informasi juga merupakan dampak positif dari penggunaan media sosial. Namun demikian, melihat perkembangan saat ini penggunaan media sosial sebagai bagian dari perkembangan teknologi informasi tidak seluruhnya dipergunakan untuk hal-hal yang positif. Bahkan, media sosial dipergunakan sebagai alat atau sarana untuk menyebarkan ideologi radikal yang menyebabkan berbagai tragedi kemanusiaan.

Oleh sebab itu, penyebaran ideologi radikal yang telah mendunia saat ini sudah sepatutnya untuk diwaspadai. Langkah preventif yang dapat dilakukan adalah dengan membatasi penyebaran konten-konten radikal di media sosial. Langkah pencegahan ini dapat dilakukan pada tingkatan regulasi, seperti menyusun dan memberlakukan peraturan atau perundangan-undangan yang mengatur penggunaan media sosial di masyarakat. Selain itu, pemerintah melalui lembaga terkait seperti Departemen Komunikasi dan Informatika dapat melakukan langkah pencegahan dengan memblokir sejumlah website yang disinyalir menyebarkan ideologi radikal. Dari segi akademik sejumlah institusi pendidikan juga dapat melakukan literasi media berupa seminar dan pendidikan kepada masyarakat. Perusahaan besar media sosial seperti Facebook, Twitter, Youtube dan Telegram pada beberapa tahun terakhir telah melakukan penutupan terhadap sejumlah akun media sosial yang terindikasi terlibat dalam penyebaran ideologi radikal.

$$
\text { Langkah pencegahan yang }
$$

dilakukan pemerintah bersama dengan departemen terkait bukan hal yang mudah. Selain, mendapatkan protes dari masyarakat karena dinilai membatasi kebebasan berpendapat dan berekspresi, website yang diblokir pada waktu yang aktif kembali dengan menggunakan nama yang berbeda. Selain itu, tampaknya perusahaan media sosial juga setengah hati dalam melakukan pemblokiran terhadap akun-akun yang dinilai memuat ideologi radikal. Hal ini disebabkan karena perusahaan media sosial sebagai representasi kepentingan kapitalisme global memiliki motif ekonomi berupa keuntungan materi dengan memanfaatkan tingginya akses terhadap penyebaran 
ideologi radikal yang dilakukan oleh para radikalis.

Berdasarkan penjelasan latar
belakang masalah tersebut, maka permasalahan utama yang ingin diangkat dalam makalah ini adalah bagaimana peran kapitalisme global dalam penyebaran ideologi radikal di sosial media? Lebih jauh, makalah ini juga ingin mengetahui bagaimana hubungan yang terjalin antar negara-bangsa dalam penyebaran ideologi radikal?, bentuk ekonomi apa yang dihasilkan dari kapitalisasi ideologi radikal? dan apa yang dilakukan jaringan global dalam meningkatkan keamanan serta pencegahan penyebaran ideologi radikal?

Perusahaan media sosial tampaknya menjadi pihak yang paling bertanggung jawab dalam penyebaran ideologi radikal di media sosial. Hal ini disebabkan karena, penyebaran konten radikal di media sosial justru dimanfaatkan sebagai pundi-pundi yang mendatangkan nilai kapital bagi perusahaan. Keuntungan tersebut didapat dari penyebaran konten-konten yang diposting melalui akun media sosial yang dimiliki oleh para radikalis. Konten radikal yang banyak diakses oleh berbagai negara tersebut, mendatangkan keuntungan melalui iklan dengan nilai yang besar. Meski mendapatkan kritik yang pedas dari berbagai kalangan terhadap praktek ini namun perusahaan media tetap melakukan praktek tersebut.

Kemampuan perusahaan media sosial untuk membendung penyebaran konten-konten negatif tampaknya masih setengah hati. Meski perusahaan media sosial telah melakukan pemblokiran terhadap sejumlah akun radikal, namun konten yang terlanjur tersebar di media sosial tidak pernah bisa benar-benar hilang. Karena konten radikal tersebut terlanjur tersebar lebih luas melalui akunakun lain yang tidak terlibat secara langsung dengan organisasi radikal namun tetap memiliki motif ekonomi, sehingga para radikalis tetap dapat melancarkan terornya meski akun yang mereka kelola langsung telah diblokir oleh perusahaan media sosial. Dengan demikian perusahaan media sosial yang berperan sebagai kapitalis global telah menjalankan perannya sebagai sarana atau saluran dalam penyebaran pesan-pesan yang memuat ideologi radikal.

\section{KAJIAN LITERATUR Dimensi Politik Globalisasi}

Menurut Steger (2003: 56-68), dalam karyanya "Globalization: a Very Short Introduction" menyatakan bahwa globalisasi dalam perspektif politik merujuk pada dua hal yaitu intensifikasi dan perluasan hubungan antar negara. Proses intensifikasi dan interelasi yang dilakukan oleh berbagai negara-bangsa di dunia tersebut melahirkan sejumlah permasalahan baru terkait dengan politik globalisasi. Permasalahan tersebut salah satunya menyangkut mengenai prinsip kedaulatan negara, batas negara dan berbagai permasalahan politik lainnya. Munculnya permasalahan tersebut disebabkan oleh perbedaan prinsip pandangan negara-bangsa dalam melihat prospek masa depan. Perbedaan prinsip tersebut terkait dengan konsep dasar yang disusun oleh setiap negara-bangsa untuk memiliki pandangan dan konsepnya sendiri dalam mengatur persoalan dalam negeri dan global.

Selanjutnya, Steger (2003:56) menjelaskan bahwa pembagian ruang, garis teritorial merupakan salah satu kegiatan yang telah dilakukan oleh manusia dalam beberapa abad terakhir untuk mengorganisasikan perbedaan politik. Konsep pembagian ruang sosial yang terjadi pada lingkup domestik dan global ini pada akhirnya turut memiliki andil dalam memunculkan pemahaman baru identitas kolektif warga tentang "siapa kita" dan "siapa mereka" yang tidak dikenal. Lebih lanjut, bagi warga negara pemahaman identitas kolektif dari sisi psikologis, sejarah dan historis menimbulkan rasa aman dan rasa percaya diri. Sedangkan, dari sisi negara-bangsa pemahaman tersebut dilakukan dengan meletakkan fondasi kepada warganya untuk mencintai dan menempatkan kesetiaan nasional terhadap bangsanya sendiri. Selain itu, negara-bangsa juga menanamkan keyakinan bahwa bangsa sendiri memiliki superioritas dibanding dengan bangsa lain dan "mengutuk" citra yang ditimbulkan oleh bangsa lain. 
Pemahaman ini perlu ditanamkan oleh negara-bangsa kepada warga negara sebagai "amunisi" untuk energi mental menghadapi perang yang mungkin terjadi di masa depan.

Steger menekankan bahwa pembagian wilayah atau teritorial merupakan bentuk konsep yang diciptakan dan "disepakati" secara bersama-sama oleh setiap negara-bangsa. Konsep yang disepakati tersebut menjadi awal dari terciptanya sistem negara-bangsa modern yang muncul pasca perdamaian Westphalia. Perdamaian yang timbul akibat dari pertentangan Katolik-Kristen ini secara tidak langsung memberikan kebebasan kepada negara-bangsa untuk memilih bentuk sistem negaranya tetap kedalam bentuk Kerajaan atau berubah menjadi Republik. Perdamaian yang merupakan bagian dari konsepsi hukum internasional ini memiliki landasan prinsip bahwa semua negara-bangsa memiliki hak yang sama untuk menentukan nasib sendiri. Selain itu, Perdamaian Westphalia juga memiliki dampak yang lain seperti adanya kekuatan politik yang tersentralisasi dengan memisahkan campur tangan agama dalam keputusan politik negara, perluasan administrasi negara, dan perkembangan diplomasi secara lebih professional.

Sistem negara modern yang diadopsi oleh negara-bangsa ini memasuki tahap perkembangan selanjutnya ketika Presiden Amerika Serikat, Woodrow Wilson menetapkan konsep 'Fourteen Points' berdasarkan prinsip penentuan nasib mandiri secara nasional. Komitmen Wilson untuk menerapkan konsep tersebut berjalan seiring dengan impian internasionalisnya untuk membangun sistem keamanan global secara kolektif dibawah naungan organisasi internasional, Liga Bangsa-Bangsa. Gagasannya untuk membentuk sistem keamanan global ini menjadi cikal bakal terbentuknya Perserikatan Bangsa-Bangsa (PBB) pada tahun 1945. Organisasi internasional antar pemerintah yang dibentuk oleh PBB memiliki tujuan sebagai kepanjangan tangan dalam melakukan kegiatan politik secara lintas batas nasional. Pada dekade tahun 1970 an, kecenderungan globalisasi ini menjadi semakin kuat ketika sejumlah negara-bangsa berkomitmen untuk bergabung bersama membentuk jaringan global interdependensi politik. Tindakan yang dilakukan oleh PBB tersebut dinilai dapat melemahkan prinsip kedaulatan nasional. (Steger, 2003: 58)

Pernyataan tersebut diperkuat oleh para kaum Hyperglobalizers yang memiliki pendapat bahwa konsep-konsep globalisasi memiliki dampak membatasi atau menurunkan peran dominan dari pemerintah negara-bangsa. Pembatasan peranan ini memiliki arti sebagai tindakan untuk memahami perubahan politik dan sosial. Dengan demikian, Hyperglobalizers menyatakan bahwa kekuatan politik saat ini terdapat pada tingkatan sosial global. Pembatasan teritorial sudah tidak lagi dipandang sebagai sebuah konsep dari sistem negara modern, tetapi sudah beralih menjadi jaringan global melalui kekuatan sektor ekonomi dan politik. Hyperglobalizers menyatakan bahwa kekuatan politik saat ini ditentukan oleh jaringan ekonomi regional yang saling terkait dalam jaringan produksi global yang tanpa batas.

Pernyataan dari kelompok Hyperglobalizers ini memunculkan perdebatan terutama terkait dengan isu politik dan ekonomi global. Kaum skeptis globalisasi menyatakan bahwa pernyataan dari Hyperglobalizers telah melecehkan peranan dominasi negara-bangsa. Dalam pandangannya kelompok ini berpendapat ekspansi kegiatan ekonomi global yang cenderung cepat dapat dikurangi dengan hukum alam pasar dan pengembangan teknologi komputer. Artinya, kelompok skeptis memiliki pandangan bahwa pembatasan wilayah masih sangat relevan dan penting. Oleh sebab itu, bentukbentuk politik konvensional dalam sistem negara-bangsa modern harus dapat beroperasi dengan baik.

Dalam globalisasi aspek ekonomi dan politik memiliki kaitan yang erat. Bentuk-bentuk ekonomi sangat bergantung pada keputusan politik. Liberasi perdagangan, deregulasi ekonomi merupakan bentuk-bentuk ekonomi yang terjadi akibat dari keputusan-keputusan politik. Pasar global kerap melemahkan kapasitas pemerintah untuk menetapkan kebijakan-kebijakan nasional. Sehingga 
tindakan tersebut membuat pemerintah sebagai entitas yang berdaulat mengalami kemerosotan. Namun demikian, konsensi tersebut tidak selalu berarti bahwa negarabangsa hanya menjadi pengamat yang tidak berdaya terhadap cara kerja kekuatan global. Pemerintah diharapkan masih dapat mengambil langkah-langkah untuk membut perekonomian negara menjadi lebih menarik bagi para investor global. Selain itu, negara-bangsa juga masih dapat melakukan kontrol terhadap bidangbidang lain seperti pendidikan, infrastuktur dan pergerakan jumlah penduduk.

Selain daripada ekonomi, globalisasi politik merupakan isu paling menonjol dalam kaitannya dengan jaringan pemerintahan global. Jaringan ini menghubungkan kekuatan-kekuatan yang saling terkait, seperti pemerintah provinsi, pemerintah kota, blok regional, organisasi internasional dan asosiasi sektor swasta baik dalam skup nasional maupun internasional. Pada tingkat provinsi dan kota, secara inisiatif telah terjalin kerjasama yang menghubungkan lintas batas antara berbagai otoritas sub-negara. Kerjasama ini menghasilkan kebijakankebijakan dan kerjasama yang permanen dengan melibatkan sedikit pengawasan pemerintah nasional dari negara-bangsa yang terlibat dalam kerjasama atau jaringan global. Kerjasama pada tahap selanjutnya dapat berkembang pada tingkatan regional, dimana organisasi internasional membuat perjanjianperjanjian multilateral secara mandiri. Sedangkan, pada tingkatan global pemerintah bergabung atau membentuk organisasi internasional seperti PBB, WTO, WHO. Keanggotaan pada level ini terbuka bagi negara-bangsa manapun dan otoritas pengambilan keputusan diberikan kepada perwakilan yang dipercaya dari pemerintah nasional.

Organisasi internasional yang berkembang menjadi badan Transworld ini menunjukkan bahwa globalisasi telah membuat negara-bangsa sulit untuk mengelola jaringan interdependensi sosial yang luas. Hal ini membuat "masyarakat sipil global' yang terdiri dari asosiasi internasional membentuk organisasi internasional non-pemerintah. Organisasi internasional non-pemerintah yang lebih dikenal dengan LSM ini merupakan organisasi yang dipersiapkan mewakili sejumlah warga biasa untuk menentang keputusan politik dan ekonomi yang dibuat negara-bangsa dan organisasi internasional antar pemerintah.

Globalisasi politik oleh para ahli diprediksi dapat memfasilitasi munculnya kekuatan sosial transnasional demokratis yang bermuara di lingkungan masyarakat global saat ini. Perspektif ini mengarah pada munculnya demokrasi kosmopolitan yang menjadi dasar bagi pluralitas identitas yang berkembang dalam struktur toleransi dan akuntabilitas bersama. Globalisasi politik yang diprediksi bergerak menuju demokrasi kosmopolitan dinilai sebagai sebuah idealisme yang gagal melibatkan perkembangan politik saat ini pada tingkat kebijakan publik.

\section{Ideologi Radikal}

Salah satu reaksi dari globalisasi yang terjadi didunia adalah munculnya fundamentalisme ditengah masyarakat. Fundamentalisme yang identik dengan sebuah gerakan ini merupakan pemikiran yang memiliki cita-cita untuk kembali pada pokok-pokok akar ajaran yang diyakini yaitu ajaran-ajaran tentang agama. Ajaran agama pada pengertian disini tentunya tidak merujuk hanya pada satu ajaran agama tertentu. Tetapi, pemikiran fundamentalisme hadir atau ada pada setiap agama yang ada di dunia, seperti Islam, Kristen, Hindu, Budha dan ajaran agama lainnya. (Khanif, et al, 2017:17).

Meski makna fundamentalisme secara harafiah masih mengalami pro kontra, namun doktrin fundamentalisme agama kerap dihubungkan dengan gerakan radikal. Doktrin tersebut oleh para kaum radikal dijadikan sebagai sebuah ideologi gerakan yang berbasiskan pada pandangan agama. Kaum radikal atau disebut juga dengan radikalis ini menginginkan adanya perubahan terhadap sistem pemerintahan dan tatanan sosial sesuai dengan ajaran agama. Djuyandi (2017:44) menyatakan bahwa kaum radikal yang menghendaki perubahan sosial dan politik secara drastis kerap menggunakan kekerasan untuk mewujudkan cita-citanya. Hal tersebut 
senada seperti diungkapkan oleh Shadily (1984), yang menyatakan radikalisme merupakan gerakan politik yang mendapatkan dukungan dari para pengikutnya untuk menempuh jalur ekstrem dengan cara kekerasan dan drastis. Lebih dalam, Shadily menyatakan bahwa cara-cara ekstrem tersebut merupakan konsekuensi berdasarkan pada ideologi yang mereka anut untuk mencapai cita-cita bersama.

Nasution dalam Ali, et al (2018:5), menyatakan bahwa radikalisme memiliki makna sebagai sebuah gerakan yang kolot, kaku dan kerap mengajarkan kekerasan dalam menyebarkan ideologi yang mereka yakini. Lebih lanjut, Nasution mengemukakan radikalisme agama disebabkan karena pemahaman yang sempit terhadap teks-teks agama.

Selanjutnya, menurut Partanto, et al (1994) ideologi radikalis merupakan paham politik yang menginginkan adanya perubahan dan perombakan besar dalam segala struktur sosial sebagai jalan untuk mencapai tujuan atau jalan menuju taraf kemajuan yang lebih baik. Berdasarkan pada penjelasan diatas yang menekankan pada makna perubahan kemajuan yang lebih baik, pengertian ideologi radikal dipandang menjadi sesuatu yang positif. Dengan demikian ideologi radikal dipandangan sebagai hal yang positif atau negatif bergantung dari bagaimana para radikalis tersebut merealisasikan dan mengekspresikannya.

\section{Media Sosial}

Media sosial merupakan salah satu bentuk dari media baru yang masuk dalam kategori jejaring sosial. Media sosial tidak saja menjadi bagian dari perkembangan teknologi informasi, tetapi media sosial juga memiliki kontribusi dalam pembentukan budaya, bahasa dan aspek ekonomi. Media sosial yang memiliki karakter berbeda dengan media tradisional, merupakan media siber yang saat ini paling banyak dimanfaatkan oleh berbagai bidang kerja, seperti jurnalistik, hubungan masyarakat, pemasaran bahkan politik (Nasrullah, 2017:9).

Penyebaran informasi tanpa batasan waktu dan ruang serta memiliki karakter interaktif menjadi keunggulan utama dari media ini. Informasi yang dibagikan melalui media sosial menjadi bagian yang sangat penting. Hal ini disebabkan karena para pengguna media sosial tidak saja menjadi khalayak tetapi turut ambil bagian dalam memproduksi konten, berinteraksi terkait dengan konten yang diproduksi dan membagikannya kepada jaringan sosial yang dimilikinya.

Informasi menjadi bentuk komoditas baru di era digital ini. Informasi dapat dipertukarkan menjadi nilai kapital yang sangat menguntungkan (Thrift, 2005 dalam Gane, et al, 2008). Perusahaan media sosial menjadi pihak yang sangat menikmati keuntungan dari sisi informasi ini. Berbagai sisi informasi dari pengguna dapat digunakan sebagai data untuk merencanakan strategi pemasaran dan penentuan target konsumen (Nasrullah, 2017:21). Bahkan, Fuchs (2014) menyebut pengguna media sosial sebagai pekerja digital yang tidak perlu dibayar. Artinya, para pengguna media sosial "bekerja" dengan iklas memproduksi konten untuk mendatangkan keuntungan bagi perusahaan media sosial.

Media baru dengan munculnya media sosial juga telah membawa perubahan ke aspek lain kehidupan masyarakat, antara lain, perubahan pola komunikasi dan pola berpikir ditengah masyarakat saat ini. Perubahan pola komunikasi tersebut berawal dari bentuk komunikasi yang nyata menjadi komunikasi dalam bentuk virtual. Sedangkan, perubahan pada pola berpikir mengacu pada tindakan masyarakat yang hanya berpikir instant dalam memberikan pendapat atau merespon sebuah isu yang beredar di media sosial. Pola pikir yang cenderung disruptif ini sekilas memberikan kesan bahwa terpaan media sosial membuat pikiran seseorang menjadi kerdil dan sempit.

Tampaknya karakter dari media sosial inilah yang menjadi sasaran para kaum radikalis dalam menyusupkan ideologi radikal ke masyarakat melalui media sosial. Media sosial dimanfaaatkan sebagai sarana propaganda untuk menyebarkan ideologi radikal, dan mempengaruhi masyarakat. Tujuan akhir dari penyebaran ideologi radikal tersebut adalah untuk menarik dukungan 
masyarakat dan merekrut masyarakat untuk mau berjuang bersama dengan kaum radikal melakukan serangkaian aksi teror. Dengan demikian, berdasarkan pada penjelasan awal diatas maka objek kajian pada makalah ini mengacu pada penyebaran ideologi radikal yang dilakukan di berbagai platform media sosial dan mencoba membongkar hubungan serta peranan kapitalisme global dalam penyebaran ideologi radikal tersebut.

\section{METODE PENELITIAN}

Topik Pembahasan pada makalah ini mengacu kepada beberapa konsep yang terdapat dalam teori dimensi politik globalisasi yang dijabarkan oleh Manfred B Steger. Konsep dalam teori tersebut mencakup dimensi penting dalam politik globalisasi. Dimensi-dimensi tersebut menjelaskan tentang peran kedaulatan negara, identitas kolektif, dan keamanan serta ekonomi. Konsep-konsep tersebut memiliki keterkaitan dengan beberapa kajian yang menjadi fokus dalam penulisan makalah ini yaitu teritorial negara, nasionalisme dalam globalisasi serta peran sektor keamanan dan ekonomi dalam globalisasi.

Peran kedaulatan negara memiliki makna bahwa teritorial negara merupakan dampak yang ditimbulkan dari globalisasi. Munculnya batas negara-bangsa yang terjadi secara global merupakan akibat dari dorongan perbedaan prinsip dan pandangan negara-bangsa dalam menatap masa depannya masing-masing (Steger, 2003:56). Perbedaan ini turut mendorong setiap negara- bangsa untuk selalu bertanggung jawab menjaga wilayah teritorialnya. Bagi negara yang melaggar teritorial sebuah negara-bangsa tertentu maka sejatinya negara tersebut telah mengusik prinsip yang dipercaya oleh sebuah negara-bangsa. Konsep pertama ini merupakan bagian yang akan dideskripsikan dalam hubungannya dengan ambisi dari para radikalis yang memiliki keinginan untuk merubah pandangan atau prinsip dari sebuah negara melalui penyebaran ideologi radikal di media sosial.

Selain itu, konsep yang juga akan menjadi fokus kajian adalah makna dari identitas kolektif. Identitas kolektif merujuk pada persamaan identitas yang muncul akibat dari persamaan sejarah asal yang dialami atau dimiliki oleh sekelompok manusia yang tinggal dan hidup bersama dalam satu wilayah yang sama. Identitas kolektif ini memunculkan rasa percaya diri diantara warga negara bangsa untuk mencintai negaranya sendiri. Jiwa nasionalisme dari warga negara inilah yang menjadi modal bagi pemerintah untuk "dimanfaatkan" sebagai energi untuk menghadapi gangguan keamanan yang mungkin terjadi di masa depan.

Peran keamanan dan ekonomi juga dua hal yang tidak bisa dipisahkan dalam globalisasi. Konsep ini mengacu kepada peranan dari negara-bangsa untuk menunjukkan eksistensinya dalam memberikan kontribusinya di dunia internasional. Penekanan kerjasama pada konsep ini adalah keterlibatan negarabangsa dalam menjaga keamanan wilayah regional secara bersama-sama. Selain itu, aspek ekonomi dalam kerjasama regional antar negara-bangsa turut menjadi perhatian pada konsep ini. Kerjasama regional antar negara-bangsa dalam segi ekonomi memiliki tujuan untuk melawan bentuk dominasi negara besar yang ingin menguasai negara dunia ketiga.

Untuk dapat membahas dan menjelaskan konsep dengan masalah yang menjadi fokus kajian pada makalah ini, penulis menggunakan pendekatan metode kualitatif deskripstif. Metode ini digunakan penulis untuk menjelaskan hasil pengamatan terhadap fenomena yang terjadi di media sosial dalam hubungan dengan penyebaran ideologi radikal. Berdasarkan pengamatan tersebut data yang terkumpul akan dideskripsikan dan diinterpretasikan secara sistematis, terstruktur dan faktual serta akurat. Sedangkan, teori digunakan sebagai "alat" untuk membuka dan melihat fenomena penyebaran konten ideologi radikal di media sosial.

Pengamatan dilakukan dengan menyusuri jejak digital dari konten-konten radikal yang pernah diunggah maupun dibagikan melalui media sosial. Tujuan dari penelusuran dan pengamatan terhadap jejak digital ini, diharapkan dapat 
membantu penulis mendapatkan data awal untuk menjelaskan hubungan antara peran kapitalisme global dengan kaum radikal. Hal ini dilakukan sebagai bagian untuk membuktikan bahwa kapitalisme global dengan kaum radikal memiliki "hubungan" yang bertentangan dan sekaligus menguntungkan.

\section{HASIL DAN PEMBAHASAN}

Pada masa globalisasi saat ini manusia mengalami kehidupan yang serba tidak menentu. Jika pada masa dulu perebutan kekuasaan ditandai dengan luasnya wilayah jajahan yang berhasil direbut dengan menggunakan senjata, pada masa kini bentuk dari "penguasaan" sebuah negara dilakukan dengan menggunakan teknologi informasi. Tentara dengan persenjataan yang modern tidak lagi berkuasa dalam melakukan kekerasan terhadap kemanusiaan, namun saat ini muncul kekuatan sipil yang turut melakukan kekerasan dengan memanfaatkan teknologi informasi. Artinya, secara singkat perkembangan teknologi informasi pada era globalisasi saat ini menjadi "senjata" ampuh untuk melakukan teror atau dengan kata lain perkembangan teknologi informasi berdampak pada munculnya bentuk "kolonialisme" baru.

Ancaman keamanan melalui teknologi informasi ini tidak saja datang dari negara lain atau dari pihak kapitalis global, namun ancaman tersebut juga datang dari pihak sipil yang turut memanfaatkan teknologi informasi sebagai sarana untuk mencapai tujuannya dengan melakukan serangkaian teror. Masyarakat sipil yang kerap melakukan teror terhadap pihak oposisi biasa disebut dengan teroris atau kaum radikal. Hal ini disebabkan karena para masyarakat sipil ini kerap melakukan kekerasan dalam mencapai tujuan politik. Meski tidak seluruhnya, namun gerakan sipil ini kebanyakan dimotivasi oleh keyakinan dalam menjalankan perintah-perintah agama (Winarno, 2011:171).

Perkembangan jaman merubah segalanya, termasuk strategi dari kaum radikalis dalam menjalankan aksi terornya. Pada era perkembangan digital saat ini kaum radikalis tidak lagi sepenuhnya mengandalkan aksi kekerasan. Meski masih dilakukan, namun aksi kekerasan yang dilakukan oleh kaum radikalis tersebut justru didokumentasikan dan "diproduksi" untuk disiapkan menjadi konten yang disebarkan dalam akun media sosial . Pemanfaatan media sosial yang berbasis pada perkembangan teknologi informasi ini menjadi sarana propaganda yang berdampak sangat luas.

Perubahan strategi yang dilakukan oleh para kaum radikalis ini tampaknya cukup berhasil dalam menyebarkan teror dan ideologi radikalnya. Konten kekerasan dan ideologi radikal yang didengungkan melalui media sosial tersebar ke pelosok dunia. Penyebaran ideologi radikal tersebut berhasil mempersatukan pengguna media sosial di seluruh dunia yang memiliki pandangan sama dengan kaum radikalis. Keberhasilan kaum radikal dalam menyebarkan konten kekerasan dan ideologi radikal direspon keras oleh negara-negara dunia dengan memberikan kecaman kepada kaum radikalis

Meluasnya penyebaran ideologi radikal ke penjuru dunia melalui media sosial, membuat orang berusaha mengaitkannya dengan keamanan global. Berbagai aksi terorisme baik yang terjadi didaerah konflik atau aksi serangan teror yang dilakukan secara individu maupun berkelompok cukup mengkhawatirkan. Karena aksi tersebut bisa terjadi kapan saja dan dimana saja. Aksi ini semakin menjadi sebuah ancaman karena kaum radikalis tidak saja menggunakan senjata dan bom untuk melakukan teror, tetapi saat ini sudah menggunakan media sosial untuk menambah dampak ketakutan ditengah masyarakat. . Politisi Amerika Serikat, Ted Poe melalui tulisannya di cnn.com tidak saja mengecam apa yang dilakukan oleh kaum radikal, tetapi juga mengecam perusahaan media sosial yang berkontribusi dalam menyediakan sarana penyebaran ideologi radikal (cnn.com) Oleh sebab itu, untuk menghadapi permasalahan terkait dengan aksi penyebaran ideologi radikal yang merambah ke aksi jaringan teroris secara global diperlukan langkah-langkah pengamanan bersama seperti membentuk kerjasama penanggulangan aksi terorisme 
secara regional, internasional maupun global.

Perusahaan media sosial sebagai representasi dari kapitalisme global memiliki peranan yang sangat penting dalam penyebaran ideologi radikal. Peran tersebut dilakukan dengan "memelihara" penyebaran ideologi radikal di media sosial. Hal ini dilakukan oleh perusahaan media sosial untuk mengeruk keuntungan dari konten radikal yang diunggah ke media sosial. Media sosial seperti facebook, twitter, youtube merupakan media yang hidup dari iklan. Iklan-iklan tersebut akan ditampilkan pada halaman linimasa pengguna media sosial berdasarkan target pasar dari para pengguna media sosial tersebut.

Hubungan antara perusahaan media sosial dengan kaum radikalis pada dasarnya merupakan hubungan simboisis yang saling menguntungkan. Meski tampak keduanya mewakili ideologi yang berbeda, namun sejatinya hubungan keduanya secara tidak langsung merupakan hubungan yang saling menguntungkan. Perusahaan media sosial mendapatkan keuntungan dari konten yang diunggah oleh kaum radikalis, sedangkan kaum radikalis mendapatkan keuntungan dengan penyebaran ideologi radikal melalui media sosial.

Selain dari aspek ekonomi, kedua "kutub" yang memiliki ideologi berbeda ini sama-sama memiliki tujuan dan citacita untuk membuat dunia memiliki hanya satu identitas. Tujuan dari globalisasi adalah terwujudnya demokrasi kosmopolitan (Steger, 2003:66). Sedangkan, tujuan dan cita-cita dari kaum radikalis adalah merubah negara berlandaskan demokrasi menjadi negara yang berlandaskan ideologi khilafah atau ideologi yang sesuai dengan kepercayaan dari ajaran agama tertentu.

Menurut Held (1999:376-413)

Demokrasi kosmopolitan merupakan citacita kosmopolitan yang mencakup pengaturan hukum internasional, jaringan antar institusi pemerintah dan non pemerintah serta munculnya masyarakat sipil internasional. Lebih lanjut, Held menjelaskan bahwa demokrasi kosmopolitan tidak lagi memerlukan keberadaan dari suatu negara-bangsa dalam sistem internasional. Aspek kebijakan dan regulasi disusun berlandaskan pada prinsip keterbukaan, musyarawarah dan konsultasi. Prinsipprinsip yang terbuka tersebut diharapkan dapat mengakomodir aspirasi individu secara praktis. Meski masih banyak perdebatan mengenai konsep dari demokrasi kosmopolitan ini, namun konsep ini menjadi wacana bagi tatanan dunia baru bagi para kaum kapitalis global. Hal ini karena konsep kesetaraan global, mencapai tujuan demi kebaikan, kemakmuran dan keadilan sosial yang merata diantara para negara-bangsa.

Nurdin (2017:32) menambahkan ada beberapa syarat yang harus dipenuhi agar demokrasi kosmopolitan dapat hidup, yaitu: Pertama, Pengembangan yang berkelanjutan dari sumber daya dan dukungan dari jaringan yang menjalin kerjasama secara regional, internasional dan global. Kedua, pengakuan secara terbuka penambahan jumlah penduduk dalam komunitas politik yang berbeda termasuk sosial, budaya, ekonomi dan lingkunganhidup.Ketiga, mengembangkan pengertian bahwa "keberuntungan kolektif" membutuhkan solusi demokrasi yang kolektif-lokal, nasional, regional dan global. Keempat, Meningkatkan hak dan kewajiban demokrasi dalam pembuatan dan pelaksanaan huku nasional, regional dan internasional. Kelima, Pemindahan kapasitas militer bangsa yang mengalami peningkatan jumlah ke agensi dan institusi antar bangsa dengen demiliterisasi dan pengaburan batas sistem perang negara.

Sedangkan, khilafah merupakan sistem pemerintahan yang wilayah kekuasaannnya tidak terbatas pada satu negara, melainkan banyak negara di dunia, yang berada di bawah satu kepemimpinan dengan dasar hukumnya adalah syariat islam. Secara lebih singkat, ideologi khilafah adalah sekumpulan negara yang dijadikan satu kekuasaan, daalam satu pemerintahan, dengan satu kepemimpinan (kompas.com). Berdasarkan pada definisi dari dua konsep demokrasi kosmopolitan dan ideologi khilafah, maka dapat disimpulkan bahwa kedua ideologi ini sejatinya memiliki kemiripan, yaitu berkeinginan menerapkan satu ideologi yang berlaku secara global. 
Bagi negara dunia ketiga, konsep globalisasi dengan demokrasi kosmopolitan dan konsep ideologi khilafah merupakan dua konsep yang tidak ada bedanya. Kedua konsep tersebut tidak lepas dari kepentingan untuk menguasai aset-aset dari negara-bangsa dunia ketiga.

\section{KESIMPULAN}

Kapitalisme global memiliki peranan penting dalam penyebaran ideologi radikal di media sosial. Penyebaran ideologi radikal yang dilakukan oleh sejumlah kelompok ekstrimis di media sosial merupakan keuntungan kapitalis global yang selalu siap disimpan kapan pun. Tindakan tersebut mendatangkan keuntungan yang besar bagi perusahaan media sosial. Keuntungan tersebut didapatkan dari penyebaran konten-konten yang diposting melalui akun sosial media yang dimiliki oleh kaum radikal. Kemampuan pengelola media sosial untuk membendung penyebaran konten-konten negatif justru tidak dilakukan. Pengelola media sosial menjalankan perannya sebagai sarana atau saluran dalam penyebaran pesan-pesan yang memuat ideologi radikal.

Usaha untuk mengatasi aksi terorisme baik secara langsung maupun langkah preventif melalui media sosial harus meliputi usaha untuk menghilangkan akar penyebabnya. Selain itu, penegakan hukum sesuai dengan perundangan yang berlaku juga merupakan langkah dapat dilakukan untuk membendung aksi teror dan penyebaran ideologi radikal. Langkah selanjutnya adalah menjalin kerjasama secara internasional dengan melakukan pendidikan terhadap polisi, membentuk kerjasama khusus untuk membentuk satuan anti teror, bertukar informasi dan melakukan pencegahan secara bersamasama melalui teknologi informasi. Melalui faktor internal negara, membangkitkan jiwa nasionalisme sehingga segala bentuk "penjajahan" yang dilakukan baik dari pihak kapitalis maupun dari kaum radikalis dapat ditangkal dengan semangat cinta tanah air.

\section{REFERENSI}

\section{Buku}

Ali, Hasanuddin et.al. 2018. Radicalism Rising Among Educated People. Jakarta: Alvara Research Center.

Deutsch, Morton et.al. 2016. Handbook Resolusi Konflik: Teori dan Praktek.Bandung: Nusa media

Depdikbud. 1995. Kamus Besar Bahsa Indonesia. Edisi Kedua. Jakarta: Balai Pustaka

Fuchs, C. 2014. Social Media a Critical Introduction. Los Angeles: SAGE Publications, Ltd

Gane, N., \& Beer, D.2008. New Media, The Key Concepts.New York:Berg.

Hardiman, F. Budi. 2009. "Demokrasi Deliberatif: Menimbang 'Negara Hukum' dan 'Ruang Publik' dalam Teori Diskursus Jurgen Habermas. Jakarta: Penerbit Kanisius

Held, David et.al. 1999. "Global Transformations: Politics, Economics, and Culture”. Stanford: Stanford University Preess.

Khanif, Al, Et al. 2017. Pancasila dalam Pusaran Globalisasi. Jember: LKiS

Nasrullah, Rulli. 2017. Media Sosial: Perspektif Komunikasi, Budaya dan Sosioteknologi. Bandung: Simbiosa Rekatama Media

Nurdin, Ismail. 2017. Etika Pemerintahan: Norma, Konsep, dan Praktek Etika Pemerintahan.Yogyakarta: Lintang Rasi Aksara Books

Priyono, AE, Et al. 2014. Media Sosial Alat Gerakan Sipil. Jakarta: Public Virtue Institute

Partanto, Pius A, Et.al.1994. Kamus Ilmiah Populer. Surabaya: Arkola

Robertson. Ann E. 2007. Terorism and Global Security. New York: Fact on File, INC

Steger. Manfred. B. 2003. Globalization: A Very Short Introduction. New York: Oxford University Press

Shadily, Hassan. 1984. Ensiklopedi Indonesia.Ichtiar Baru-Van Hoeve dan Elsevier. Jakarta: Publishing Projects 
Winarno, Budi. 2011. Isu-isu Global Kontemporer. Yogyakarta: CAPS.

\section{Website}

https://tirto.id/revolusi-yang-berawal-darimedia-sosial-cqNP

https://www.cnnindonesia.com/nasional/2 0161124075029-12-174911/kronologikasus-buni-yani-penyebar-video-ahoksoal-al-maidah

https://nasional.kompas.com/read/2016/05 /04/08005961/BNPT.500.WNI.Menuju.Su riah.untuk.Gabung.ISIS

https://edition.cnn.com/2015/02/25/opinio $\mathrm{n}$ /poe-terrorism-social-media/index.html

https://nasional.kompas.com/read/2017/06 /12/07462921/jika.khilafah.berdiri.apakah. pancasila.tetap.ada.

\section{Jurnal}

Surahman, Sigit (2013). Dampak Globalisasi Media Terhadap Seni dan Budaya Indonesia. Jurnal Komunikasi Lontar, Volume 2, Nomor 1, Jan - April 2013, halaman $29-38$.

Rully (2018). Efektifitas Iklan Negatif di Media Sosial dalam Politik di Indonesia. Jurnal Komunikasi Lontar, Volume 6, Nomor 1, Januari-Juni 2018, halaman 69-79

\section{Media Cetak}

Kompas, 27 Desember 2017, Era Pertarungan Digital Dimulai

Kompas, 19 Jamuari 2018, Melawan Narasi kebencian

Kompas, 20 Juni 2018, Menghadang Radikalisme di Medsos 